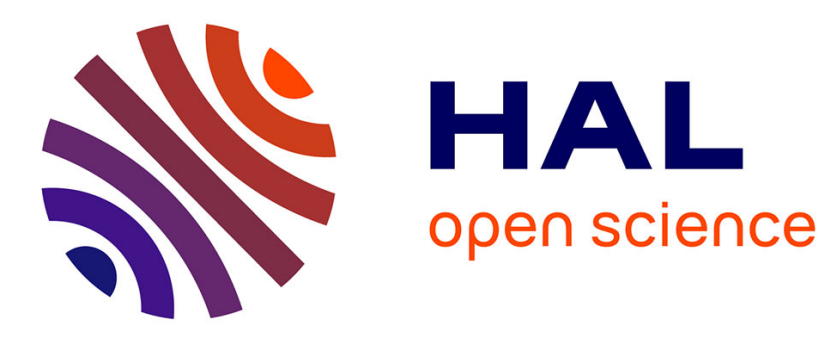

\title{
The determinants of innovation adoption
}

Corinne Autant-Bernard, Jean-Pascal Guironnet, Nadine Massard

\section{To cite this version:}

Corinne Autant-Bernard, Jean-Pascal Guironnet, Nadine Massard. The determinants of innovation adoption. 2010. halshs- 00550343

\section{HAL Id: halshs-00550343 \\ https://shs.hal.science/halshs-00550343}

Submitted on 27 Dec 2010

HAL is a multi-disciplinary open access archive for the deposit and dissemination of scientific research documents, whether they are published or not. The documents may come from teaching and research institutions in France or abroad, or from public or private research centers.
L'archive ouverte pluridisciplinaire HAL, est destinée au dépôt et à la diffusion de documents scientifiques de niveau recherche, publiés ou non, émanant des établissements d'enseignement et de recherche français ou étrangers, des laboratoires publics ou privés. 
The determinants of innovation adoption

Corinne Autant-Bernard, Jean-Pascal Guironnet, Nadine Massard

Décembre 2010 


\section{GATE Groupe d'Analyse et de Théorie Économique Lyon-St Étienne}

93, chemin des Mouilles 69130 Ecully - France

Tel. +33 (0)4 72866060

Fax $+33(0) 472866090$

6, rue Basse des Rives 42023 Saint-Etienne cedex 02 - France

Tel. +33 (0)4 77421960

Fax. $+33(0) 477421950$

Messagerie électronique / Email : gate@gate.cnrs.fr

Téléchargement / Download : http://www.gate.cnrs.fr - Publications / Working Papers 


\title{
The determinants of innovation adoption
}

\author{
Corinne Autant-Bernard ${ }^{1}$ \\ Université de Lyon, Lyon, F-69003, France \\ Université Jean Monnet, Saint-Etienne, F-42000, France \\ CNRS, GATE Lyon St Etienne, Saint-Etienne, F-42000, France. \\ Jean-Pascal Guironnet \\ University of Caen, CREM CNRS 6211

\section{Nadine Massard} \\ Université de Lyon, Lyon, F-69003, France \\ Université Jean Monnet, Saint-Etienne, F-42000, France \\ CNRS, GATE Lyon St Etienne, Saint-Etienne, F-42000, France.
}

November 2010

\begin{abstract}
:
Using a sample of 46000 EU firms from the Community Innovation Survey, this paper analyses the drivers of innovation adoption. In contrast to most empirical studies on innovation diffusion in which a specific technology is analyzed, this study covers several countries and industries in the European Union. Following Van de Ven and Van Praag (1981), Heckman's method is applied in a context of binary endogenous variable to explain the choices made by firms regarding innovation. Distinctions are made between the internal generation of innovation and the adoption of innovation produced by others, as well as between different types of adoption (product $v s$. process and cooperation-based adoption $v s$. isolated adoption). The study is focused on the impact of users' features and their cooperation with suppliers on the adoption choices. The results point out that cooperation is a key driver of adoption choices. Usual determinants such as firm size, absorptive capability or exports would foster generation of innovation instead of adoption.
\end{abstract}

Keywords: Innovation adoption, Innovation diffusion, Community Innovation Survey, Process adoption, Product adoption

JEL codes: 031, 033

\footnotetext{
${ }^{1}$ Corresponding author: Corinne Autant-Bernard, 6 rue basse des rives, 42023 Saint-Etienne cedex 2, France, phone: +33(0) 477421 966, fax: +33(0) 477421950 ; autant@univ-st-etienne.fr.
} 


\section{Résumé :}

A partir d'un échantillon de 46000 entreprises de l'Enquête Communautaire sur l'Innovation, (CIS), cet article analyse les facteurs à l'origine de l'adoption d'innovation. Contrairement aux travaux empiriques antérieurs qui considèrent seulement une technologie spécifique, cette étude couvre plusieurs industries et plusieurs pays de l'Union Européenne. Suivant l'approche suggérée par Van de Ven et Van Praag (1981), la méthode d'Heckman est appliquée dans un contexte de variable endogène dichotomique afin d'expliquer les choix des entreprises en matière d'innovation. On distingue en particulier la génération d'innovation et l'adoption d'innovation produites par d'autres, ainsi que différents types d'adoption (produit vs. procédé, adoption basée sur la coopération vs adoption réalisée de manière autonome). L'étude met l'accent sur l'impact des caractéristiques des utilisateurs et de la coopération avec les offreurs. Les résultats révèlent que la coopération est un facteur clé des choix d'adoption. Les déterminants plus traditionnels tels que la taille des entreprises, leur capacité d'absorption ou leur niveau d'exportation apparaissent en revanche comme déterminants de la génération d'innovation plutôt que de l'adoption de technologies existantes.

Mots clé : Adoption d'innovation, Diffusion d'innovation, Enquête Communautaire sur l'Innovation, Adoption d'innovation de procédé, Adoption d'innovation de produit

Codes JEL : 031, 033 


\section{Introduction}

Although it is usual in academic research to relate technological change to R\&D investments or the generation of new technologies, needless to say that it is only when these new technologies are broadly introduced into the economy that their benefits will be realized (Hall and Khan, 2003). Thus, the diffusion stage of the technological change process becomes almost the foremost phase. An extensive literature, belonging to various research fields (agriculture, health, economics and management among others) studies this process of innovation diffusion. ${ }^{2}$ In this process, a specific attention has been devoted to the adoption choices, e.g. to the decision to start using a new technology, this latter being product innovation, process innovation or management innovation. A lot of empirical evidence has been provided, pointing out the existence of an S-shaped curve in most cases, with a low rate of adoption in the early stage, followed by a rising rate until a saturation point. In spite of this common feature, empirical evidence points also to the great variety of the speed of adoption. The length of each phase can greatly vary, from one technology to another, but also for a similar technology, from one country or one region to another ${ }^{3}$. This raises the question of the underlying mechanisms of the innovation adoption process. The theoretical literature identifies several potential determinant of the adoption choice. However, we still miss a systematic empirical evaluation of these factors. The current literature is based on case studies that do not provide a general overview. Most of the empirical studies focus on a specific technology and very few cross country comparisons or cross industry comparisons are provided $^{4}$.

This paper tries to fill in this gap by providing a microeconomic analysis of the determinants of innovation adoption covering several countries and industries in the European Union. More specifically, the aim of the study is to analyse the drivers of innovation adoption through the development of proper measures and the analysis of the main determinants of this process in the European Union. Based on the Community Innovation Survey (CIS), we suggest an indicator of innovation adoption at the firm level which is based on the distinction between firms developing their own innovation and firms declaring that their innovations have been

\footnotetext{
${ }^{2}$ See for instance Geroski (2000) for a review.

${ }^{3}$ See Massini (2004) for a review of recent refinements in standard epidemic models and their empirical estimation.

${ }^{4}$ See Canepa and Stoneman (2004) who use data derived from a number of standalone surveys in different countries and show the difficulties of comparative studies on innovation diffusion.
} 
developed "mainly together with other enterprises or institutions" or "mainly by other enterprises or institutions" Such an indicator allows us to distinguish between different kinds of adoption (process vs. product adoption, collaboration-based adoption vs. isolated adoption). The adoption choices made by firms are then explained by the users' characteristics, together with an assessment of the role played by cooperation between users and suppliers.

It is worth noticing however, that using CIS entails some consequences. Firstly, the information about adoption is available for innovative firms only. Theoretically, we should therefore consider the innovation diffusion process as the result of a two-step decision process: being innovative or not, at the first step, and adopting external technologies or producing them internally, at the second step. Methodologically, this means that our estimation is exposed to the well-known "selection bias" (Heckman, 1979) requiring an appropriate estimation method. The probabilities to adopt new technologies are estimated following the method of Van de Ven and Van Praag (1981). This approach applies the Heckman's method in a context of binary endogenous variable. It is extended in order to cope with the double selection bias that arises when dealing with the different types of innovation adoption.

Secondly, when focusing on the analysis of the reasons that lead to adopt an existing product or process, instead of developing it within the firm, the study suffers from some limitations. The database does not allow us to cover all the potential determinants of adoption. In particular, supplier features but also cultural and institutional characteristics of the environment are not included. These unobserved features are accounted for all together through industry and country dummies, only their net influence is therefore observed.

The remainder of the paper is organized as follows. The main theoretical hypotheses are discussed first (section 2). Then, the model and the data are presented in section 3 . The results are discussed in section 4 and the last section summarizes the main conclusions.

\section{Related literature and main hypotheses}

Different theoretical approaches have been pursued to describe the rationale behind the main characteristics of the adoption process. Mainly developed within the innovation diffusion literature, they generally confuse the decision to innovate with the decision to adopt an external technology. We'll see however that they are mostly adaptable to our own analytical 
framework which consists in distinguishing among innovative firms the ones which best participate to the diffusion process by their choice to adopt external innovations instead of developing them on their own.

Basically, three main conditions for innovation adoption can be pointed out: ${ }^{5}$

- being aware of the new technology, which is stressed by epidemic models,

- being able to use and adapt the new technology, which refers basically to demand models, although is also related to the supply side models (where the ability of suppliers to improve their products or processes or to develop complementary inputs foster the adoption process),

- profitability of adopting the new technology, which depends on the price, on the expected returns, and on the level of risk.

These three conditions rely primarily on the characteristics of the potential users, but also on the actions and features of the suppliers of the new technology (Hall and Khan, 2003), as well as on the interactions between users and suppliers and on the regulatory environment.

\subsection{Users' characteristics as determinants of innovation adoption}

From the demand side perspective, several factors are likely to affect the ability to be aware of the new technologies and the ability to use and adapt them (what is referred to in the literature as the absorptive capacity), as well as the expected returns of adoption: user's investments in human capital and R\&D, user's organizational innovation and users' size and market features, among the main ones, as we analyse below in depth.

\section{User's investments in human capital}

The investments made by users in human capital play a crucial part in their ability to adopt innovations. This human capital is often a condition to be aware of the new technology and to be able to use it. Along with the specific institutional framework of each economy, the role played by human capital in the absorptive capacity of a firm or an economy is well documented. Nelson and Phelps (1966) argue, for example, how imitation and adoption imply

\footnotetext{
${ }^{5}$ See also Rogers (1995) and Hall (2005) for different presentations of these conditions.
} 
an investment in human capital. Hence, the higher the human capital of a lagging economy, the faster will be its technological catch-up. ${ }^{6}$

For example, "reverse engineering" on which a considerable part of innovation diffusion relies, is more likely to be performed by engineers than by low skilled workers. A more formal discussion of this hypothesis can be found in the works of Benhabib and Spiegel (2005) or Basu and Weil (1998) where the adoption of very different technologies may imply an increasing difficulty for the follower. Human capital may facilitate the absorption of these distant technologies acting as an enhancing factor for the diffusion of innovation.

\section{User's investments in $R \& D$}

Similarly, investments in R\&D made by users can help adapting the new technology. The change in the conception of knowledge points out the role of R\&D as an absorptive capacity (Cohen and Levinthal 1989, 1990, Jovanovic and Rob, 1989). A firm's absorptive capacity largely depends on the level of prior related knowledge owned by the firm. Also, the ability of a firm or an economy to use the results of research efforts made by other firms or other public and/or private research establishments depends on its ability to understand them and to assess their economic potential.

It is important to note here that while the literature on innovation diffusion and absorptive capacity insists on the necessary innovative capabilities (especially $R \& D$ capacities) of adopting firms, it is also clear that firms that can develop innovations in-house are likely to have higher innovative capabilities than firms that only acquire new technology developed by others (Arundel, 2007; Huang et al., 2010). Consequently, human capital and R\&D capacities would have a mixed effect, positive on the capacity to innovate but negative on the adoption choice.

\footnotetext{
${ }^{6}$ Nelson and Phelps (1966) argue how "it is clear that the farmer with a relatively high level of education has tended to adopt productive innovations earlier than the farmer with relatively little education [...] for he is better able to discriminate between promising and unpromising ideas [...] The less educated farmer, for whom the information in technical journal means less, is prudent to delay the introduction of a new technique until he has concrete evidence of its profitability".
} 


\section{User's organisational innovations}

Adoption of innovation often requires organisational innovation ( ICT adoption is a striking example). Thus, the ability of users to make organisational changes may enhance their ability to use new technology, and therefore improve innovation diffusion (see Battisti et al. 2007 on the ICT case).

Moreover, the kind of organizational structure is an important determinant of how knowledge flows inter and intra-firms. Lane and Lubatkin (1998) or Lenox and King (2004) analyze, for example, how the organizational structure of a firm influence the internal communication processes therefore shaping its absorptive capacity.

\section{Size of the user's firm}

Size may impact on the profitability of adoption. Indeed, it reduces the level of risk since it is distributed over a large number of products. It also reduces the financial constraint. User's financial means are required to be able to adapt the new technology and to lower the critical level of profitability. Indeed, as argued by Maskus (2000), imitation usually takes the form of adaptations of existing technologies to new markets. Imitation and adaptation of leading-edge technologies imply a cost for the technological follower. This determines the extent of technology flows from a best-practice technological frontier to the rest of firms or countries. The costliness of imitation is widely observed and acknowledged in theoretical and empirical literature. Maskus et al (2004), Mansfield et al (1981), Coe and Helpman (1995) or Behnabib and Spiegel (2005) point out how the cost of both the adaptation and imitation of technologies discovered at the frontier (or in other technological sectors) is usually positive but relatively lower than the cost of innovation. The larger the firm, the higher the financial means devoted to the adaptation and imitation of technologies. It should not be forgotten however, that, when considering the choice between adoption and internal innovation, the cost argument implies that large firm are more likely to innovate internally than to adopt technologies produced elsewhere.

Furthermore, the size of the firm is usually regarded as an important factor shaping the absorptive capacity. A good deal of empirical evidence seems to show how larger firms are more likely to exploit their existing internal knowledge in order to diffuse knowledge internally and increase their productivity (i.e. Levinthal and March, 1993; Dougherty and Heller, 1994). Based on a join analysis of intra- and inter-firms technological diffusion, 
Battisti et al. (2007) state however that, although large firms adopt innovations more frequently than smaller firms, once the technology is adopted smaller firms use it more intensively than larger firms. Consequently, larger firms would be more likely to choose internal innovation against adoption of external technologies.

\section{User's market features}

The main characteristics of the market faced by potential users are also likely to influence their propensity to adopt new technologies. The literature has pointed out the role played by the market share of the user (Hall and Khan, 2003). The larger the market share, the higher the incentives to adopt, because a large market share increases the ability to appropriate the returns from adoption. In addition to market share, the market dynamisms may also imply higher rates of adoption. In probit or rank models, demand growth is stressed as a positive factor of innovation diffusion, because it increases the expected returns. It should be noted however, that such arguments are globally relevant to explain the propensity of firms to innovate. It is therefore, not obvious to anticipate their influence on the choice between innovation and adoption.

\section{Previous adopters}

Finally, based on epidemic models, we can state that the number of previous adopters on the market plays also a crucial part in innovation diffusion. According to the epidemic models, the use of new technology is constrained by the number of people knowing the existence of the new technology. As time proceeds, the experience of users leads to the spreading of knowledge on the existence of the technology. Therefore, the probability of being aware of one technology rises with the number of previous adopters. The information regarding how to use the new technology is also becoming more available, increasing the ability of potential users to adopt it. Moreover, the profitability may change along the diffusion path. Indeed, a high number of previous adopters may give rise to higher expected returns. This would be the case in particular if network externalities arise. Conversely, the risk associated with adoption decreases with the number of adopters. Adopter's heterogeneity however must be considered as a factor explaining the disequilibrium nature of the diffusion process although most diffusion studies neglect this aspect (Massini, 2004). 


\subsection{Suppliers' characteristics and interaction between suppliers and users as determinants of innovation adoption}

As they concern the suppliers of the new technologies, these determinants are more specific to the adoption process than those presented above which often apply to innovation as well as to adoption. Most of the supply side models do not deal directly with the adoption phase of the innovation diffusion process. They instead put the emphasis on the ability to diffuse a technology. However, this can impact for a part on the adoption choice made by users.

According to Rosenberg (1972) on the supply side there are several important factors for the diffusion of innovation, for instance, the improvements made to the technology after its introduction, the invention of new uses for the old technology, the development of complementary inputs such as user skills and other capital goods, and the like. In a more global approach, Rosenberg (1972) points also out the characteristics of the institutional context and the regulatory environment as influencing factors.

More recently, the theoretical and empirical literature on innovation diffusion and technology transfers shows that interactions between users and suppliers are required for innovation diffusion to occur and that the regulatory environment is an influencing determinant of the quality of these interactions.

\section{Supplier's innovative and financial features}

New technologies are rarely commercialized in their very first version. They need to be improved and adapted to the specific needs of users. The capability of suppliers to improve their technology but also to provide users with complementary products is very important. Moreover, the price is often high at the first stage of innovation diffusion. In order to ensure a higher rate of diffusion, suppliers have to perform innovation in order to reduce the costs. For these reasons, the $R \& D$ and innovative capacity of new technology suppliers is thus essential. Supplier's financial means are of course important to be able to adapt the new technology (to cover the R\&D costs) as mentioned above. But financial means play also a role to inform potential users, for instance as in Tonks (1986) who puts the stress on the advertising costs. The edition of users' guide may also generate important expenditures (in the aerospace industry for instance). 
As stressed by the epidemic models, these different factors stemming from supplier features (cost reduction, complementary products, etc) are facilitated by the number of adopters already present on the market. In other words, innovation diffusion may be driven by suppliers and users interaction, as reviewed next.

\section{Interaction between users and suppliers}

An important result of both the theoretical and empirical literature is that technology transfers do not happen spontaneously. The distinction made by Rogers (1995) on hardware and software indicates that some information is tacit, and requires interpersonal contact to be transmitted. Therefore, being aware of the technology and being able to adapt it requires effective contacts between suppliers and users. Interactions between users and suppliers are required for innovation diffusion to occur. These relationships support two distinct kinds of exchange between suppliers and users:

- Exchanges of tangible assets: Innovation diffusion may rely on flows of products and services that allow imitation, reverse engineering, technology transfers, ... For this reason, trade is an important driver of innovation diffusion. Coe and Helpman (1995) and Coe et al. (1997) argue that international R\&D spillovers are substantial and that trade is an important channel of such spillovers. Markusen (1989), Verspagen (1997) and Keller (1999) analyzed initially the impact of trade (and in particular of the import of intermediates) on the diffusion of technology and innovation within and across countries. Empirical studies such as Syrquin and Chenery (1989) or Sachs and Warner (1995) provided a solid evidence of the positive impact of trade on technology diffusion and growth.

- Exchanges of intangible assets: Ideas are not freely accessible to everyone. They are instead, at least partly, embodied into people (Lucas, 1988). Therefore, the diffusion of tacit knowledge and their absorption would rely on effective interpersonal interactions. Studies exploring this issue consider two main kinds of interactions: the face to face relationship, on the one hand, and the human capital mobility, from one institution to another or over space, on the other hand. More recent research suggests that, beyond direct relationships, the integration within networks is a key factor for knowledge diffusion and thereby for innovation diffusion (Autant-Bernard et al. 2010). 
From this viewpoint, the organisational structure of the economy as well as the regulatory environment plays a crucial part.

\section{Regulatory environment}

A specific field of research refers to the role played by the intellectual property rights regime $^{7}$. We will not review it here. Let us just note that it has an impact on all the conditions of the innovation diffusion: it produces positive effects by improving awareness about the new technologies, it also gives incentives to suppliers to improve the technology or to develop complementary technologies; but on the opposite, it generates negative effects on the price, since royalties have to be paid. Therefore, its impact on innovation diffusion is not unidirectional especially when it is considered as an alternative to internal innovation. If, on the one hand, increasing the protection of IPRs theoretically ensures the innovator to be rewarded for its investment in R\&D it is argued, on the other hand, how strengthening IPRs protection significantly raises the costs of imitation and thereby hinders adoption processes. The use of strategies to increase appropiability is expected to increase with the level of investment in activities that produce novel innovations. Therefore technology adopters are expected to use fewer appropriability strategies that $R \& D$ performing firms (Huang et al., 2010).

Other researches point that concentration facilitates for suppliers to adapt the technology to potential users (see Lundvall, 1992). At the same time, competition increases adoption by lowering prices. Market structures are also pointed as a determinant of the level of interactions between users and suppliers. The information and technology flows are favoured by vertical and horizontal integration. This latter increases effective contacts and the flows of both tangible and intangible assets. Spatial concentration also facilitates for users to be aware of the new technology, and reduces the risk by reinforcing local trust. The information and communication technologies ease interpersonal relationship and they give a better access to information, thus facilitating awareness about the new technology.

The determinants of innovation adoption are therefore numerous and not surprisingly, no empirical study covers all of these potentials drivers. ${ }^{8}$ In order to provide a better overview of

\footnotetext{
${ }^{7}$ See Surinach et al. (2009) for a review.

${ }^{8}$ Studies based on micro data generally consider the users and suppliers features and their impact on innovation diffusion whereas other studies more often based on macrodata analyse the impact of the regulatory environment
} 
the determinants of innovation adoption, the remainder of this paper implements an econometric model based on CIS microeconomic data covering different EU countries and several industries.

\section{Methodology}

Whereas existing analyses of the determinants of innovation adoption refer to specific technologies, we will consider here the determinants of adoption of innovation in general terms, without specifying any particular technology.

Compared to previous studies, we also cover a various set of potential drivers of innovation adoption. It will not be possible however to cover all the potential factors. The main feature of the regulatory environment, as well as the supplier's characteristics cannot be accounted for with a micro database focussing on potential adopters. The focus is therefore upon the users' features and their cooperation with suppliers. We believe that the most important drivers are considered here, but it is important to keep in mind that the error term as well as the dummy variables may bring together a set of other determinants of innovation adoption, for which we will measure only a net effect.

\subsection{Use of the Community Innovation Survey}

This research work is based on a sample of 46010 observations coming from the CIS 3 micro anonymized dataset provided by Eurostat. It analyses innovative activities carried out between 1998 and 2000 by EU firms.

In the CIS survey, the definition of innovation covers both the generation of innovation and the adoption of such innovation. Therefore, it can be used to analyse the process of innovation diffusion, by identifying innovation that relies on an adoption process. We first explain how we proceed to distinguish adoption and generation of innovation. Then, we suggest indicators likely to characterize the nature of adoption.

(IPR, competition and market feature, trade, FDI, etc). Some most recent studies include also the interactions between users and suppliers. See Surinach et al. (2009) for a review. 
For each firm, the CIS gives information on the way the product and process innovations have been developed. Firms have to choose between three answers:

- innovation developed mainly by the firm

- innovation developed mainly together with other firms or institutions

- innovation developed mainly by other enterprises or institutions.

Therefore, we will consider that innovation adoption occurs as soon as the firm declares that its process or product innovations have been developed "Mainly together with other enterprises or institutions" or "Mainly by other enterprises or institutions".

It is worth mentioning that our definition does not strictly account for adoption in the sense that innovation developed together with other enterprises can rely on knowledge sharing more than on innovation diffusion. However, as mentioned in the literature review (section 2) most studies stress the importance of effective collaboration to adapt the technology and make it suitable for the adopter. This is thus relevant to consider that in many such cases, innovation diffusion occurs.

Furthermore, firms are asked about their "main" way of innovation. Therefore, some firms are excluded from the definition above while they do rely on innovation adoption, but this is not their main way of innovation (some firms answering that their innovations have been developed mainly within the enterprises or the group may be at the same time adopters of innovation developed elsewhere). We are therefore driven to consider that adoption is done by the firms whose product or process innovations are developed mainly together with other firms or mainly by other enterprises, and that all the information they provide regarding inputs and outputs concerns this kind of innovation. This implies also that, we do not have, for each firm, the number of innovations that fits with the definition, which prevents us from accounting for the extent of adoption.

In spite of these drawbacks, the CIS provides us with a large sample of microeconomic data, covering $14 \mathrm{EU}_{\text {countries }}^{9}$ and most industries, allowing for the first time a systematic evaluation of the determinants of innovation adoption within the EU.

\footnotetext{
${ }^{9}$ Belgium, Bulgaria, Czech Republic, Estonia, Spain, Greece, Hungary, Iceland, Lithuania, Latvia, Norway, Portugal, Romania and Slovakia.
} 


\subsection{Model}

The dependent variable measures the fact that the firm has chosen an adoption strategy against the internal innovation strategy. More precisely, the decision to adopt an innovation (product or process) is estimated by means of a binary choice model. The profit associated with adoption is considered to be the latent variable. Since a measure of this profit is not available, a probit model is used where the dependent variable takes value 1 if firm $i$ adopted a product or a process innovation (developed by others or in collaboration with others) and 0 otherwise. Adoption is assumed to occur if the associated payoffs are positive.

For each firms, adoption is assumed to occur if and only if the expected profit, noted $\Pi_{i}$ is positive. So, the probability that adoption occurs in firm $i$ is $P_{i}=P\left(\Pi_{i}>0\right)$. For each firm, the profit associated with adoption is given by:

$$
\Pi_{i}=V_{i}+\xi_{i}
$$

where $V_{i}$ is a function of all the characteristics of firm $i$ likely to impact on the decision to diffuse. $\xi_{i}$ is a random perturbation. A linear expression is chosen for $V_{i}$ :

$$
V_{i}=\beta X_{i}
$$

where $X_{i}$ is the vector of the observable characteristics of firm $i$ and $\beta$ is the vector of the parameters to be estimated.

Only innovative firms (in terms of product or process) are included in the sample, so that the absence of adoption cannot be explained by the absence of innovation. Therefore, the analysis focuses upon the reasons that lead to adopt an existing technology or a process, instead of developing it within the firm.

The firm features are drawn from the theoretical studies detailed in section 2 of this paper. Eight variables are included:

First of all, the equation of innovation adoption includes the turnover of the firms, (LNTURN) in order to measure the firm size effect. As mentioned above, a positive effect of this variable can be expected on the propensity to adopt a technology, via the absorptive capacity of the firms. However, a large size may also reduce this propensity due to the fact that we consider here the choice to adopt against the choice to innovate internally. 
The absorptive capacity of firms does not only rely on a size effect. It is usually associated with the level of skill within the firm or with the Research and Development investment made by the firm. For this reason, we include in the equation the number of workers with higher education (LNEMPHI) as well as the total innovative expenditure (LNRTOT). A high level for these two variables is likely to facilitate the adoption process. However, it also enhances the capacity of firms to internally innovate. Estimations will allow us to better appreciate their relative role in these two processes.

As specified above, IPR may also play a crucial part in the way innovation is likely to diffuse across firms. The variable PATENT takes the value 1 if the firm uses patent protection and 0 otherwise. Note however that this variable is observed at the firm level. Therefore it cannot account for the impact of the IPR intensity that prevails in the sector. This variable measure to what extent firms with patenting policies are more likely to adopt innovation than firms with no patent policy. On the one hand, a positive sign of the associated parameter can be expected. Since adoption may lead to new innovation, patenting firms may have more incentives to adopt. On the other hand however, a negative sign may also occur if there exists a trade off between own firm innovations and adoption. In this case, patenting activities may characterize firms that mainly innovate by themselves, whereas mainly adoptive firms would have a low propensity to patent.

Adoption of innovation is also closely linked in the literature to the ability of firms to adapt their organizational structures. The dummy variable ORGA is introduced to account for this potential effect. A positive sign of the associated coefficient is expected. Firms that introduce organizational innovation would be more likely to adopt new technologies.

The public financial supports have also been highlighted as a positive factor for innovation adoption. A dummy variable, labelled PUBLIC, accounts for this potential effect. A positive coefficient is expected, even though this could depend on the relative weight of the diffusionoriented public aids.

In order to account for innovation adoption driven by trade, the level of exports of the firm (LNEXP) in introduced. A positive impact would indicate that the innovation diffusion effect exceed the competitive effect due to international pressure. This latter might indeed incite innovative firms to be leader instead of follower.

The interactions between users and suppliers are proxied by a dummy variable (COOP) that takes value 1 if the firm has been involved in cooperation activities for its innovation. 
In addition to these variables, we also include in the estimation a dummy variable indicating whether the firm belongs to a group or not (GP). ${ }^{10}$ Although the literature does not stress this point, it appears that this can affect the ability to adopt an innovation. On the one hand, one can consider that belonging to a group increases the opportunities to adopt technologies. On the other hand, due to the way our dependent variable is built, a negative sign may be expected. Indeed, innovations adopted from the remainder of the group are excluded of our definition of adoption. Therefore, if firms that belong to a group rely on innovation developed by the remainder of the group, this will reduce their share of adoption based on external innovation only (which is our definition of adoption). More practically, it is also important to control for this characteristic because some firm may have answered certain items referring to the whole group instead of the firm only.

Finally, both industry and country dummies are included. These variables measure the net effect of all the industry and country specific features (Competition, IPR system, geographical distribution, etc.) that impact the innovation process.

From a methodological point of view, adoption choice is only observed by the enterprises which have decided to innovate. Our estimation is therefore exposed to the well-known "selection bias" (Heckman, 1979). Consequently, we choose to estimate the probabilities to adopt new technologies following the method of Van de Ven and Van Praag (1981). This approach $^{11}$ applies the Heckman's method in a context of binary endogenous variable.

For this reason, we estimate three main equations. Equations (i) explains the innovation decision meanwhile equations (iii) and (iv) explain the innovation adoption decision. Equation (i) can be referred as the selection equation. This model $(i)$ allows for the calculation of the Inverse Mills' Ratio (IMR) for the computation of the model (iv). Equation (iv) in Table 1 is our main equation of interest. Equation (iii) is the model of adoption estimated by a standard probit method, without selection bias correction, in order to allow the comparison with equation (iv) including IMR. Equation (ii) is an alternative selection equation that was estimated to check the robustness of equation $(i)$. It is estimated to distinguish the effects of exports (LNEXP) from the crossing variables of the model $(i)$.

\footnotetext{
${ }^{10}$ This is an item from CIS. A firm belongs to a group when more than $10 \%$ of its capital is owned by another firm.

11 This method (also used by Sollogoub and Ulrich, 1999) includes a heteroscedastic correction for robust standard errors.
} 
In order to respect identification condition, equations ( $i$ ) and (ii) (related to innovation) include variables that are different from the one included in the adoption equations (iii and $i v$ ). Concerning identification condition, at least one variable of the model $(i-i i)$ must be excluded from model (iii-iv). EST is a dummy variable indicating that the firm was newly established during the period 1998-2000. The variable EST is considered sufficiently correlated with the innovation decision but not correlated with the adoption decision. This variable is likely to impact negatively the decision to innovate. This is due to the definition of innovation retained in the CIS. It is clearly mentioned in the CIS user guide for the respondent that, in all cases, the innovation or improvement must be considered in reference to the enterprise. They may not necessarily be innovations or improvements for the market or relatively to the enterprises of your sector (or of any other firm). An additional item is devoted to product innovations that are new to the market as well. Therefore, even if some new firms are set up because they provide new product or process compare to other firms, these innovations are not new in reference to the firm previous activity. As a consequence, new established firms are unlikely to be registered as innovating in the CIS. A firm with only one or two years of life is indeed less likely to change its product or process than older firms.

Other structural changes faced by the firm during the period 1998-2000 are also included. The variable TURNINC is a dummy variable that takes value 1 if the firm increased its turnover by $10 \%$ or more, due to merger with another enterprise or part of it. Similarly, the variable TURNDEC takes value 1 for firms that experienced a decrease in their turnover of $10 \%$ or more due to sale or closure of part of the enterprise. A positive impact of TURNINC is expected. The merger with another enterprise often goes together with a re-organization of the production process and/or with a redefinition of the firm product range. Conversely, the sale or closure of part of the firm is usually associated with a reduction phase of the firm activity, rarely associated with dynamism in terms of innovation.

Following Mairesse and Mohnen (2002), a size variable (LNWTURN) is also added in the model $(i-i i)$. This variable captures the firm turnover. In order to make the specification of our innovation equation different from our adoption equation however, this variable is crossed with the industry specific effects. LNWTURN is thus the enterprise sales weighted by the share of sales generated by the industry to which the enterprise belongs. This measure of size reflects access to finance, scale economies, and differences in the organization of work. Therefore, a positive sign of the coefficient associated with this variable is expected. The group membership variable (GP) is included as well. Firms that are members of a group are 
expected to benefit, for instance, from intra-group knowledge spillovers and internal access to finance.

This first stage includes also the variable LNEXP. The rate of export is known as a factor that stimulates competition pressure. Therefore a positive impact on innovation is expected. The other explanatory variables that are included in our adoption equation (COOP, PUBLIC, ORGA) cannot appear into this first stage. These variables are observed for innovative firms only. Similarly, the industry dummies are not introduced in these first stage equations. The correlation with LNWTURN is such that multicolinearity would arise in a specification including industry dummies.

Estimations are first run on the whole sample. The aim is to study the determinants of the adoption of an innovation, this latter being product or process innovation. One can think however that the underlying mechanisms are different according to the nature of innovation. In order to assess the very existence of such differences, estimations are then run separately for product innovation and process innovation.

\section{Results}

In the first section, the determinants of innovation adoption in product and process are discussed while in the second section we comment the innovation adoption according to the nature of innovation.

\subsection{Innovation Adoption in both product and process}

The preliminary results are reported in table 1. Innovation equation results are reported in columns (i) and (ii), while columns (iii) and (iv) report the adoption equation results, respectively without and with the selection bias correction. We firstly briefly comment on the innovation equation results. After that we focus on adoption equations, our main equations of interest.

Model (i) and (ii) reveal that the firm size, measured by the firm turnover, weighted by the industry turnover (LNWTURN) as well as GP (i.e. membership of a group) exert a positive impact on the firm propensity to innovate. These results are consistent with those obtained in 
previous studies (Mairesse and Mohnen, 2002). In the same way, the number of workers of higher education level (i.e. LNEMPHI) influences positively and significantly the probability to innovate. A positive effect is found for the firm exportations (LNEXP). The crossing variables of LNEXP with the type of market - local (i.e. LOCMAR), national (i.e. NATMAR) and international (i.e. INTMAR) - suggest a greater benefice of exportation with a higher competition (i.e. NATMAR and INTMAR). This positive role of foreign exposure is consistent with the results obtained by Mairesse and Mohnen (2005). Using a dummy variable indicating whether or not the international market is the main market or not, they observe a positive and significant impact on innovation. Lastly, new established enterprises (EST) have smaller probabilities to innovate. The variables TURNINC ${ }^{12}$ (i.e. an increase of turnover of $10 \%$ due to merger with other enterprise) and TURNEC (i.e. a decrease of $10 \%$ of turnover due to closure of an enterprise part) have remarkable symmetric effect, respectively positive and negative.

From the model (iv), the inverse Mills' ratio is not significant. This correction captures some negative trends of intercept and the correction on the other variables is weak. Despite these results, we choose to comment our results from (iv), since this model include a weak correction of selection bias.

Our results suggest that the variables influencing positively the probability to innovate influence negatively the probability to adopt a new technology. ${ }^{13}$

The global quality of the model is not very high. We succeed in predicting innovation adoption behaviour for $63 \%$ of the sample only. Several other specifications have been tested but none of them increases the explanatory power.

The firm turnover (expressed in logarithm, LNTURN) exerts a positive and significant impact, supporting the idea of a positive size effect on innovation adoption. The coefficient associated with research expenditure (LNRTOT) has the expected sign. The significance however, disappears once the selection bias is accounted for. The amount of R\&D does not appear as a specific feature of adopting firms, compare to firms that generate innovation.

On the opposite, the number of workers with a higher education (LNEMPHI) has a significant and negative coefficient. This is consistent with the fact that only innovative firms are considered in our sample. Firms that do not adopt innovation are firms that innovate by

\footnotetext{
${ }^{12}$ This variable also reflects a structure change and probably a need of new technology.

${ }^{13}$ This result is also confirmed by the sign of estimated coefficient of the inverse Mills' ratio.
} 
themselves. Therefore, they hire a larger number of high skilled workers. Among innovative firms, those with the lowest number of high skilled workers are more likely to build their innovative strategies on external knowledge, and thus to adopt innovation developed by other firms.

The variable PATENT exerts a negative impact as well. Firms that base their innovation strategy on legal protection are primarily those who generate internal innovation.

[insert table 1 about here]

The coefficient associated with the dummy variable GP has a negative sign, which was the expected sign. Firms that belong to a group have lower rates of adoption. This is due to our definition of adoption. Within group adoption is recorded as generation of innovation, and not as adoption.

The idea of organizational innovation as a pre-requisite to adopt technology developed outside is only partly confirmed. The coefficient of the corresponding variable (ORGA) is significant at a $10 \%$ threshold only. This does not mean organizational innovations are not necessary, but they do not play a very specific role on adoption compared to "internal" innovation.

According to the positive coefficient associated with the variable PUBLIC, public financial support would provide incentives to adopt. Public funding of innovation would be efficient to foster adoption of innovation, more than generation of innovation. This could result from the type of instruments used by policy makers, but it can also result from a different level of incentives associated with generation and adoption of innovation. One may hypotheses that incentives to generate innovation (due to temporal monopoly power) are high enough to lead firms to produce innovation. Incentives associated with innovation adoption would conversely be more reduced, and public policies would have a more critical impact on firm choices.

Regarding the channels through which trade may impact on innovation adoption, the negative effect of LNEXP (the amount of exported sales expressed in logarithm) is unexpected. Theoretical model as well as empirical studies have shown the positive impact of trade on innovation adoption. Once again, we must be careful in interpreting this coefficient. Compared to innovations developed within firms, exports exert a negative effect on innovation adoption. However, the global impact on innovation remains positive. This 
interpretation is clearly confirmed by our first stage estimation. In the innovation equation, LNEXP has a positive and significant coefficient. Therefore, it appears that exports impact positively on both generation and adoption of innovation, compared to the non innovative choice.

The effect of cooperation on adoption is conversely positive. Among innovative firms, the ones with cooperation activities are more likely to adopt innovation, while non cooperative firms are more likely to generate innovation. This result corroborates the theoretical hypothesis. Cooperation is a powerful driver of innovation adoption. It should be noted however, that the potential impact of cooperation on the propensity to innovate cannot be addressed here, since the cooperation variable is observed for innovative firms only.

\subsection{Innovation Adoption according to the nature of innovation}

Innovation adoption may be driven by different factors according to the nature of innovation. In order to evaluate these potential differentiated effects, this second part explores separately firms that introduce product innovations and those that introduce process innovations.

\section{Product Innovation Adoption}

We consider here a sub-sample of firms, those that innovate in product (being they innovative in process as well or not). This way, we are going to analyse the impact of our explanatory variables on the decision to adopt a product innovation or to develop it within the firm. Table 2 gives the results obtained for the same specifications as in Table 1. A selection bias arises once again in this estimation. Information regarding product adoption is available for product innovative firms only. Therefore, in a first stage, the propensity to innovate in product is estimated.

The equation selection $(v)$ is estimated using all the observations in the sample. It differs from selection $(i)$ since the dependent variable takes value 1 if the firm has introduced product innovation during the period 1998-2000 and 0 otherwise (e.g. if firm has not introduced innovation at all, or if it has introduced process innovation only). The lambda parameter accounting for the selection bias is not significant and the results obtained for equation ( $v i)$ and (vii) are very similar. 
They show that the prediction power of the model is higher than on the whole sample. Regarding the control variable, the effect of human capital (LNEMPHI), intellectual property strategy (PATENT) and belonging to a group (GP) are unchanged, with a negative sign. The impact of R\&D expenditures (LNRTOT) becomes significant and negative whereas the size, public policies and organisation innovation variables (LNTURN, PUBLIC and ORGA) becomes non significant. The influence of export becomes non significant. Cooperation is confirmed as a key driver for product innovation adoption.

[insert table 2 about here]

\section{Process Innovation Adoption}

This subsection assesses the impact of our explanatory variables on the decision to adopt a process innovation (see Table 3). We consider here a sub-sample of firms that innovate in process. The selection bias we have to deal with here is due to the propensity to innovate in process.

The selection equation (viii) does not differ from the one of product innovation. The determinants of product innovation are almost similar to those of process innovation, except for the size variable (LNWTURN) that exerts a positive impact on process innovation, as it was already observed for total innovation.

As already observed for the product innovation sub-sample, the explanatory power is slightly higher than with the whole sample. This improvement is however lower here than for product innovation if we consider the equation corrected for the selection bias $(x)$.

Several differences appear compared to product innovation. First of all, the size effect captured by the variable LNTURN is significant. Larger firms are more likely to adopt process innovation than developing them by themselves.

Public funding is also significant. Public financial support would foster process adoption more than product adoption.

Similarly to product adoption, the coefficient associated with the introduction of organizational innovation is again non significant.

Concerning the exchange variables, Export is non significant whereas cooperation remains positive and significant. The coefficient is slightly smaller however, than the one observed on 
product adoption (the marginal effects that allow us to compare the value of the coefficients are respectively 0.119 for product and 0.097 for process, and the difference is statistically significant). Cooperation would favour product innovation more than process innovation.

[insert table 3 about here]

\section{Cooperation-based adoption vs. other organization-based adoption}

Our definition of innovation adoption relies on two different items regarding the way product and process innovations occurred. The first one refers to "innovation developed mainly in collaboration with other firms or institutions", while the second one deals with "innovation developed mainly by other firms or institutions". These two items pointed two different ways of adopting innovation. Their determinants may differ.

In order to examine this issue, estimations are made considering as dependent variable the choice made by firms between the adoption developed mainly in collaboration and the adoption developed mainly by other firms or institutions.

Therefore, two selection biases are faced. The first one, as in previous estimations is due to the rejection of non innovative firms. The selection equation is the same as the equation $(i)$ reported in Table 1. In addition to that, a second selection bias can appear as our estimation is conditional to the adoption of a new technology. Indeed, in order to analyse the way adoption occurs, we reject from the sample of innovative firms, those firms that mainly develop their innovations by themselves. To say it differently, only adoptive firms are observed in our final equation. Therefore, two selection equations are needed to account for the two restrictions imposed: only innovative firms, and among them, only adoptive ones. The following diagram summarizes the potential biases: 


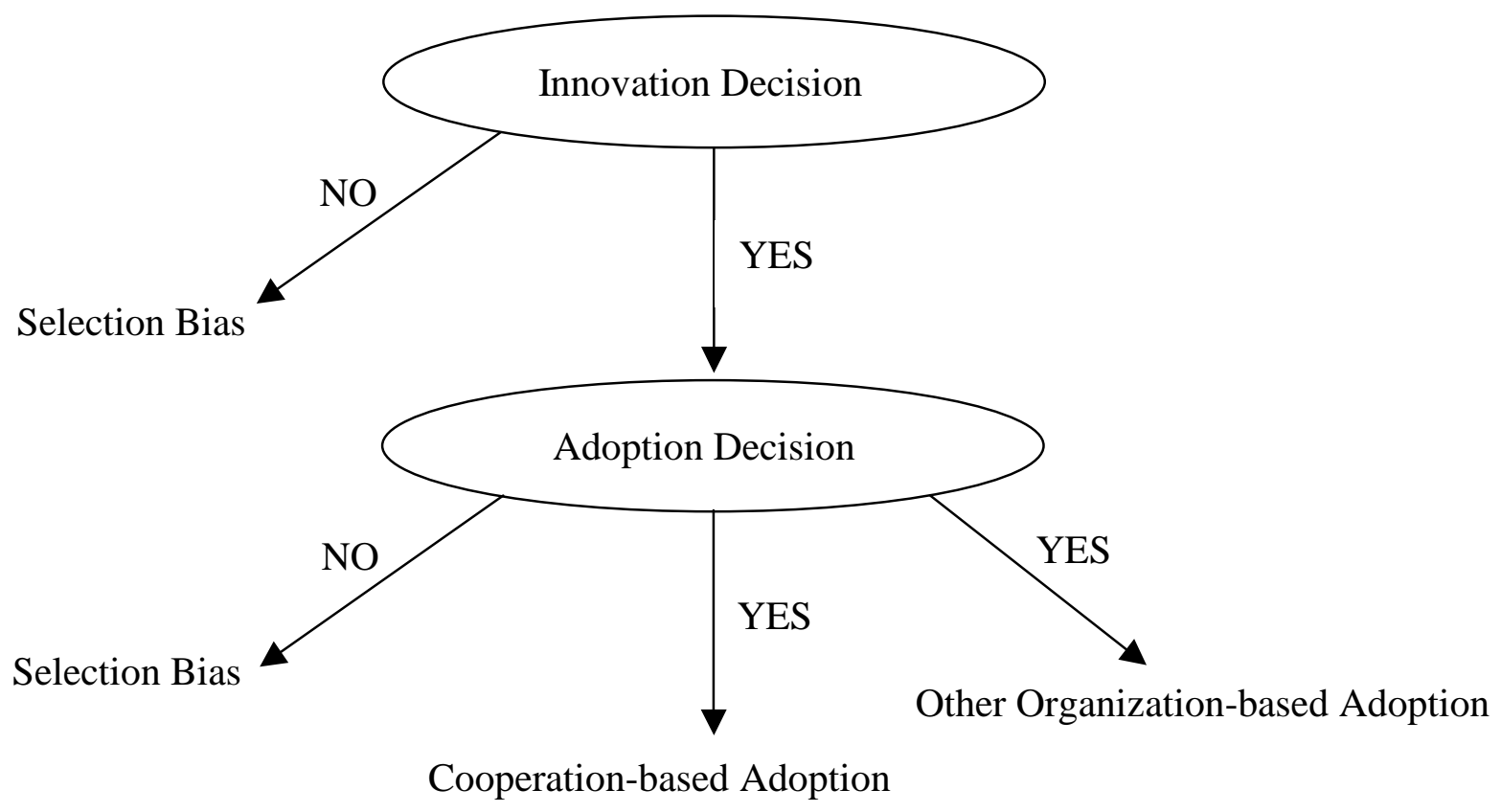

The second selection bias is corrected using estimation (iv). Consequently, model (xii) estimates the probabilities to adopt a technology developed by other organizations or institutions (model $(x i)$ is estimated without bias selection to allow comparison). ${ }^{14}$ In order to respect the identification condition, the LNTURN variable is assumed to influence the choice to adopt an innovation, and not the way adoption is made "in cooperation" or "in isolation".

The estimations are reported in Table 4 below. Concerning the selection equations, lambda is significant. The inverse Mills' ratio captures unobservable effects included in the intercept suggesting that correction is needed. The selection bias is positive, which means that the unobserved characteristics affecting positively the probability to adopt influence positively the probability to adopt product or process developed by others. Conversely, they affect negatively the probability to adopt by cooperation.

Equation (xii) shows that several significant differences appear between adoption made in cooperation and in isolation. Four explanatory variables influence significantly the way adoption is made. The higher the level of highly educated workers and export, the lower the propensity to adopt innovations developed by others (and hence, the higher the propensity to adopt innovations by cooperation). Similarly, belonging to a group and using patent protection reduce the probability of adoption made in isolation (and hence, increase the probability of adoption made by cooperation).

\footnotetext{
${ }^{14}$ See Guironnet (2006).
} 
[insert table 4 about here]

The correction of the second selection bias modifies substantially the level of significance of the variables that account for organizational innovation (ORGA) and cooperation activities (COOP). This means that, once the selection bias is accounted for there is no significant impact of these two variables on the choice between adopting innovation in collaboration or adopting innovation developed by others. This might be unexpected for the variable COOP. A positive impact on the propensity to adopt in collaboration would be more intuitive. This result may come from the specific definition of cooperation used in the CIS. It refers to formal R\&D cooperation whereas adoption would rely mainly on non R\&D and/or more informal relationship.

\section{Main conclusions}

Considering the diffusion stage as the foremost stage of innovation, many innovation public policies have focused on this stage and tried to improve the adoption process. There is no doubt however, that the global rate of diffusion within an economy is dependent of the innovative strategy of firms and especially, when they innovate, of their choice to innovate on their own or to acquire innovation made with or by other organisations. Using data from the Community Innovation Survey, this paper assesses the impact of different determinants on the adoption of innovation by firms. Several conclusions arise.

Once taken into account the variables which explain their innovative nature, several internal characteristics of the firms produce a positive impact on their choice to adopt external technologies. The size of the firm positively impacts the choice to adopt external innovation. But its effect is due to process innovation and does not occur for product innovation diffusion showing a higher importance of internal capacities for the adoption of process innovation than for product. This means that among the innovative firms, this is the smaller ones that mainly choose to internally develop their own process innovation whereas the larger firms mainly adopt process innovation produced elsewhere.

Public financial support acts as incentives to adopt. Public funding of innovation appears efficient to foster adoption of innovation, more than generation of innovation in itself. This is 
certainly due to the use of numerous transfer-oriented policy instruments and this is especially true for process adoption.

The capabilities of firms to introduce organizational changes is also positively associated with adoption, but weakly significant. Consequently, it is certainly a facilitating factor but it does not appear as a strategic factor in the choice of adoption.

On the contrary, other users' characteristics produce a negative impact on the choice to adopt. This is the case for membership of a group and absorptive capabilities measured by highly educated workers, while $R \& D$ expenditure have a negative effect for product innovation only. This runs counter traditional theoretical model as well as empirical studies. This is due to our specific sample that covers only innovative firms. The selection equation highlights that a positive impact occurs on innovation. Among the different ways of innovation however, they foster internal generation of innovation instead of adoption which is quite understandable given the importance of the internal opportunities of diffusion and exploitation of innovation offered by groups well endowed with skilled workers. The patent variable has also a negative effect which is not surprising. Intellectual property strategies are generally associated with a high rate of internal innovation.

The role of trade as a channel of innovation diffusion is measured though the export variables. In most cases it shows a negative effect on the diffusion of innovation. This runs counter traditional theoretical model as well as empirical studies but, once more, it is probably due to our specific model which distinguishes effects on innovation from effects on the diffusion of innovation. As usually supposed trade has a positive and significant effect on innovation. However, among firms which have innovative activities trade has no significant or significantly negative effect on the choice to adopt instead of generate innovation. As no variable accounting for competition has been integrated within the estimation, one can also assume that the export variable gathers international openness as well as competitive pressure effects on firms. As competition often appears as not favorable for cooperative innovation, this might explain the results.

Indeed cooperation has a clear positive effect. It increases the ability to adopt both product and process innovation. The impact is however higher on product adoption than on process adoption. Let us note also that this variable does not impact differently the choice between 
adoption made in cooperation and adoption made in isolation. Cooperation would thus be an important characteristic of adoption, whatever the way this adoption is made.

Finally it should be noted that, contrary to cooperation, many factors impact on the way adoption is made. Higher education, legal protection (patents), ownership by a group, organizational changes, public funding of innovation and exports are the main drivers of cooperation-based adoption. They conversely influence negatively adoption made in isolation.

All in all, we have disentangled the effects of various determinants of diffusion at different stages of the microeconomic processes of innovation adoption. When defining public policies instruments aiming at enhancing the rate of innovation diffusion within an economy, it should not be forgotten that they impact, at the same time, on the mere decision to innovate, on the one hand, and on the decision to adopt external technology instead of producing it, on the other hand. Concerning patents policy for example what it is important to bear in mind is the balance between innovation production (boosted by the enforcement of patent strategies) and innovation adoption (slowed down by patent strategies).

Apart from the cooperation factor which positive impact appears whatever the circumstances, the role and the importance of these determinants identified vary according to the type of innovation (product $v s$. process innovation) or to the type of adoption we have considered (by cooperation or through direct purchase from other firms). Policy makers should keep this in mind for example, when elaborating policy instruments aiming at enhancing the absorptive capacities of firms or their export and organizational performances. 


\section{REFERENCES}

Arundel A. (2007), Innovation survey indicators: What impact on innovation policy? Science Technology and Innovation Indicators in a Changing World: Responding to Policy Needs, OECD, Paris, pp. 49-64.

Autant-Bernard, C., Billand, P., and Massard, N. (2009), Innovation and Space - From Externalities to Networks, in Johansson, Karlsson et Stough (eds.), 2010, Knowledge and Talent in Regional and Global Context, Edward Elgar, forthcoming.

Basu, S., and Weil D. (1998). Appropriate Technology and Growth, Quarterly Journal of Economics, November, 113, 1025-54.

Battisti G., Hollenstein H., Stoneman P. and Woerter M. (2007), Inter and intra firm diffusion of ICT in the United Kingdom and the Switzerland. An international comparative study based on firm level data, Economics of Innovation and New technology, vol. 16(8), pp. 669-687.

Benhabib, J. and M. Spiegel (2005). Human Capital and Technology Diffusion, in Aghion P. and S. Durlauf (eds), Handbook of Economic Growth, Elsevier.

Canepa A. and Stoneman P. (2004), Comparative international diffusion; patterns, determinants, policies, Economics of Innovation and New technology, vol. 13(3), pp. 279298.

Coe D. and E. Helpman (1995). International R\&D spillovers, European Economic Review, $39,859-887$.

Coe, D., E. Helpman, and A. Hoffmaister, (1997). North-South R\&D Spillovers, The Economic Journal, 107, 134-149.

Cohen and Levinthal (1990). Absorptive capacity. A new perspective on Learning and Innovation, Administrative Science Quarterly, 35, 128 -152.

Cohen W. and Levinthal D. (1989). Innovation and learning: the two faces of R\&D, The Economic Journal, september, 99, 569-596.

Dougherty D. and Heller T., (1994). The illegitimacy of successful product innovations in established firms, Organizational Science, 5, 200-218.

Geroski, P. A. (2000). Models of Technology Diffusion, Research Policy 29(4/5), 603-625.

Guironnet (2006). La Suréducation en France: vers une dévalorisation des diplômes du supérieur?, Économie Appliquée, 59, 93-120.

Hall B. and Khan B. (2003). Adoption of New Technology, In Jones, Derek C., New Economy Handbook, Amsterdam: Elsevier Science.

Hall, B. H. (2004), Innovation and diffusion, in J. Fagerberg, D. C. Mowery and R.R. Nelson (eds.), Oxford Handbook of Innovation, Oxford University Press, Oxford.

Huang C. Arundel A. and Hollanders H. (2010), How firm innovate: R\&D, non R\&D, and technology adoption, UNU-MERIT working paper \#2010-027.

Jovanovic, B., and Rob R. (1989). The Growth and Diffusion of Knowledge, Review of Economic Studies 56, 569-582.

Keller, W. (1999) How Trade Patterns and Technology Flows Affect Productivity Growth, NBER Working Papers. 
Lane, P.J., and Lubatkin, M. (1998). Relative absorptive capacity and interorganizational learning, Strategic Management Journal, 19, 461-477.

Lenox, M., and King A., (2004). Prospects for Developing Absorptive Capacity through Internal Information Provision, Strategic Management Journal, 25, 331-345.

Levinthal, D. and March, J. (1993). The myopia of learning, Strategic Management Journal, $14,95-112$.

Lucas, R. (1988). On the mechanics of economic development, Journal of Monetary Economics, 22, 3-42.

Lundvall, B-A. (1992). National Systems of Innovation. Printer Publisher, London.

Magnani E. (2006), Technology diffusion, the diffusion of skill and the growth of outsourcing in US manufacturing, Economics of Innovation and New technology, vol. 15(7), pp. 617-647.

Mairesse, J. and Mohnen, P. (2002). Accounting for Innovation and Measuring Innovativeness: An Illustrative Framework and an Application, American Economic Review, 92, 226-230.

Mairesse, J. and Mohnen, P. (2005). The Importance of R\&D for Innovation: A Reassessment Using French Survey Data, The Journal of Technology Transfer, special issue in memory of Edwin Mansfield, 30, 183-197.

Mansfield, E., Schwartz, M. and Wagner, S. (1981). Imitation costs and patents: an empirical study, Economic Journal, 91, 907-918.

Markusen, J. (1989). Trade In Producer Services and in Other Specialized Inputs. American Economic Review, 79, 85-95.

Maskus, K., (2000). Intellectual Property Rights and Economic Development, Case Western Reserve Journal of International Law special Supplement, 32, 471-500.

Maskus, K. Saggi, K. and Puttitanun T. (2004). Patent rights and international technology transfer through direct investment and licencisng, Mimeo.

Nelson, R.R. and Phelps, E. (1966). Investment in Humans, Technological Diffusion and Economic Growth“, American Economic Review, 56, 69-75.

Rogers, E. M. (1995). Diffusion of Innovations, fourth edition. New York: The Free Press.

Rosenberg, N. (1972). Factors Affecting the Diffusion of Technology, Explorations in Economic History, 10(1), 3-33. Reprinted in Rosenberg, N. (1976), Perspectives on Technology, Cambridge: Cambridge University Press, 189-212.

Sachs, Jeffrey. D. and Warner, A. M. (1995). Fundamental Sources of Long-Run Growth, American Economic Review, May, 87, 184-188.

Sollogoub, M. and Ulrich, V. (1999). Les jeunes en apprentissage ou en lycée professionnel. Une mesure quantitative et qualitative de leur insertion sur le marché du travail. Economie et Statistique, 323, 31-52.

Suriñach J., Autant-Bernard C., Manca F., Massard N., and Moreno R. (2009) The Diffusion/Adoption of Innovation in the Internal Market, Bruxelles: European Commission DG2 - Economic papers, $n^{\circ} 384$, September.

Syrquin, M and Chenery H. (1989). Patterns of Development, 1950 to 1983, Washington: The World Bank. 
Tonks, I. (1986). The demand for information and the diffusion of new product, International Journal of Industrial Organization, 4, 397-408

Van de Ven and Van Praag, B. M. S., (1981). The Demand for Deductibles in Private Health Insurance. A Probit Model with Sample Selection, Journal of Econometrics, 17, 229-253.

Verspagen, B. (1997). Measuring Inter-Sectoral Technology Spillovers: Estimates from the European and US Patent Office Databases, Economic Systems Research, 9, 47-65. 


\begin{tabular}{|c|c|c|c|c|}
\hline Variables & $\begin{array}{c}\text { Innovation } \\
\text { Selection eq. } \\
(i)\end{array}$ & $\begin{array}{c}\text { Innovation } \\
\text { Selection eq. } \\
\text { (ii) } \\
\end{array}$ & $\begin{array}{c}\text { Adoption eq. } \\
\text { without correction } \\
\text { (iii) }\end{array}$ & $\begin{array}{c}\text { Adoption eq. } \\
\text { with correction } \\
\text { (iv) }\end{array}$ \\
\hline Intercept & $\begin{array}{c}-1.535^{* * * *} \\
(0.063)\end{array}$ & $\begin{array}{c}-1.076^{* * * *} \\
(0.046)\end{array}$ & $\begin{array}{c}-1.109 * * * \\
(0.141)\end{array}$ & $\begin{array}{l}-0.627 * \\
(0.257)\end{array}$ \\
\hline LNRTOT & $\mathrm{nc}$ & $\mathrm{nc}$ & $\begin{array}{l}0.015^{*} \\
(0.007)\end{array}$ & $\begin{array}{l}0.0002 \\
(0.003)\end{array}$ \\
\hline LNTURN & $\mathrm{nc}$ & $\mathrm{nc}$ & $\begin{array}{c}0.047 * * * \\
(0.010)\end{array}$ & $\begin{array}{c}0.044 * * * \\
(0.009)\end{array}$ \\
\hline LNEMPHI & $\begin{array}{c}0.200 * * * \\
(0.006)\end{array}$ & $\begin{array}{c}0.232 * * * \\
(0.005)\end{array}$ & $\begin{array}{c}-0.058 * * * \\
(0.012)\end{array}$ & $\begin{array}{c}-0.075 * * \\
(0.023)\end{array}$ \\
\hline PATENT & $\mathrm{nc}$ & $\mathrm{nc}$ & $\begin{array}{c}-0.176^{* * *} * \\
(0.025)\end{array}$ & $\begin{array}{c}-0.178 * * * \\
(0.024)\end{array}$ \\
\hline GP & $\begin{array}{c}0.190 * * * \\
(0.019)\end{array}$ & $\begin{array}{c}0.184 * * * \\
(0.018)\end{array}$ & $\begin{array}{c}-0.229 * * * \\
(0.028)\end{array}$ & $\begin{array}{c}-0.250 * * * \\
(0.031)\end{array}$ \\
\hline ORGA & $\mathrm{nc}$ & $\mathrm{nc}$ & $\begin{array}{l}0.076^{*} \\
(0.031)\end{array}$ & $\begin{array}{l}0.061 * \\
(0.029)\end{array}$ \\
\hline PUBLIC & nc & nc & $\begin{array}{c}0.096 * * * \\
(0.028)\end{array}$ & $\begin{array}{c}0.110 * * * \\
(0.027)\end{array}$ \\
\hline LNEXP & $\mathrm{nc}$ & $\begin{array}{c}0.024 * * * \\
(0.001)\end{array}$ & $\begin{array}{c}-0.006 * * \\
(0.002)\end{array}$ & $\begin{array}{c}-0.008 * * \\
(0.003)\end{array}$ \\
\hline COOP & $\mathrm{nc}$ & $\mathrm{nc}$ & $\begin{array}{c}0.496 * * * \\
(0.027)\end{array}$ & $\begin{array}{c}0.487 * * * \\
(0.026)\end{array}$ \\
\hline TURNINC & $\begin{array}{c}0.109 * * * \\
(0.028)\end{array}$ & $\begin{array}{c}0.105^{* * *} * \\
(0.027)\end{array}$ & $\mathrm{nc}$ & $\mathrm{nc}$ \\
\hline TURNDEC & $\begin{array}{c}-0.105^{* *} * \\
(0.034)\end{array}$ & $\begin{array}{c}-0.105 * * \\
(0.033)\end{array}$ & $\mathrm{nc}$ & $\mathrm{nc}$ \\
\hline LNWTURN & $\begin{array}{c}0.057 * * * \\
(0.005)\end{array}$ & $\begin{array}{c}0.023 * * * \\
(0.003)\end{array}$ & $\mathrm{nc}$ & $\mathrm{nc}$ \\
\hline LNEXP*INTMAR & $\begin{array}{c}0.021 * * * \\
(0.001)\end{array}$ & $\mathrm{nc}$ & $\mathrm{nc}$ & $\mathrm{nc}$ \\
\hline LNEXP*NATMAR & $\begin{array}{c}0.029 * * * \\
(0.002)\end{array}$ & $\mathrm{nc}$ & $\mathrm{nc}$ & $\mathrm{nc}$ \\
\hline LNEXP*LOCMAR & $\begin{array}{c}0.014 * * * \\
(0.002)\end{array}$ & $\mathrm{nc}$ & $\mathrm{nc}$ & $\mathrm{nc}$ \\
\hline EST & $\begin{array}{c}-0.232 * * * \\
(0.036)\end{array}$ & $\begin{array}{c}-0.361 * * * \\
(0.033)\end{array}$ & nc & $\mathrm{nc}$ \\
\hline Sectoral Dummies (7) & no & no & yes & yes \\
\hline Country Dummies (14) & yes & yes & yes & yes \\
\hline Lambda & $\mathrm{nc}$ & $\mathrm{nc}$ & $\mathrm{nc}$ & $\begin{array}{l}-0.210 \\
(0.148)\end{array}$ \\
\hline Percent concordant & 77.5 & 76.9 & 63.8 & 63.4 \\
\hline Likelihood & -23996.31 & -24027.49 & -9223.66 & -9222.63 \\
\hline LR test $(\text { Beta }=0)^{15}$ & $9848.80 * * *$ & $9786.45 * * *$ & $841.55^{* * * *}$ & $843.62 * * *$ \\
\hline LR test $($ dummies $=0)$ & $2287.84 * * *$ & $2323.87 * * *$ & $150.26 * * *$ & $152 * * *$ \\
\hline Observations & 46010 & 46010 & 14445 & 14445 \\
\hline \multicolumn{5}{|c|}{$\begin{array}{l}\text { Note : LNRTOT: Total innovation expenditure of the firm, LNTURN : turnover of the firms, LNEMPHI: higher } \\
\text { education-skilled workforce, PATENT: takes the value } 1 \text { if the firm uses patent protection and } 0 \text { otherwise, GP: } \\
\text { dummy variable indicating whether the firm belongs to a group or not, ORGA: dummy variable for organizational } \\
\text { structure PUBLIC: public financial supports, LNEXP: exports as in CIS, COOP: firms cooperate in innovation, } \\
\text { LNWTURN: Firm turnover weighted by industry turnover, INTMAR: mainly international market, NATMAR: } \\
\text { mainly national market, LOCMAR: mainly local market, EST: dummy for new established firm. } \\
\text { t-ratio are given in parenthesis level of significance: } * 10 \%, * * 5 \%, * * * 1 \% \\
\text { (Columns } i \text { and iii: without correction of selection bias. Columns ii and iv: with correction of selection bias) }\end{array}$} \\
\hline
\end{tabular}

\footnotetext{
${ }^{15}$ The LR statistics is compared to a Chi2 with the number of constraints as degree of freedom.
} 


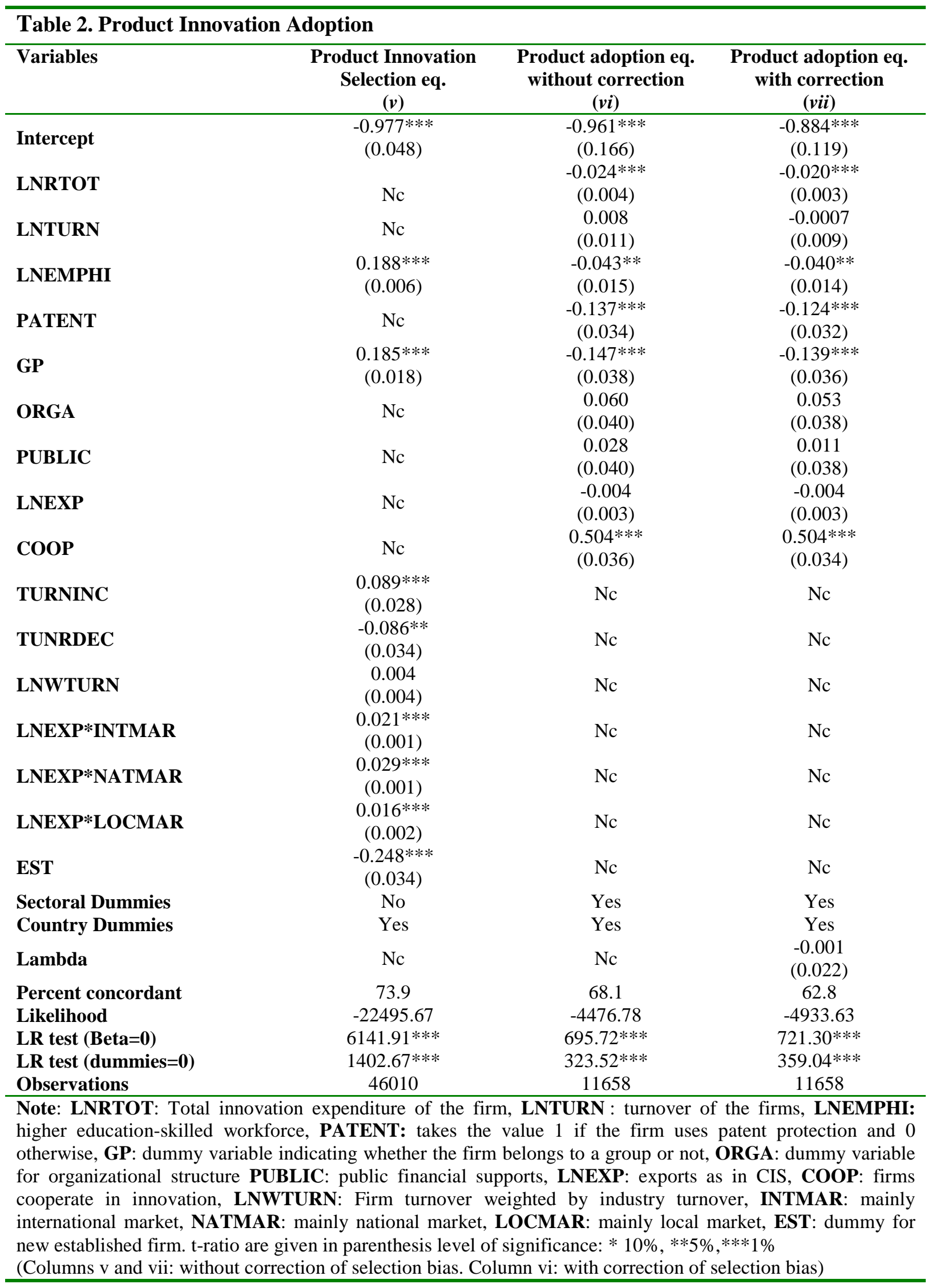




\begin{tabular}{|c|c|c|c|}
\hline Variables & $\begin{array}{l}\text { Process Innovation } \\
\text { Selection eq. (viii) }\end{array}$ & $\begin{array}{l}\text { Process Adoption eq. } \\
\text { without correction }(i x)\end{array}$ & $\begin{array}{c}\text { Process Adoption eq. } \\
\text { with correction }(x)\end{array}$ \\
\hline Intercept & $\begin{array}{l}-1.226^{* * * *} \\
(0.048)\end{array}$ & $\begin{array}{c}-1.615^{* * * *} \\
(0.162)\end{array}$ & $\begin{array}{c}-1.561 * * * \\
(0.144)\end{array}$ \\
\hline LNRTOT & $\mathrm{Nc}$ & $\begin{array}{c}0.012^{* *} \\
(0.004)\end{array}$ & $\begin{array}{l}0.007 \\
(0.004)\end{array}$ \\
\hline LNTURN & $\mathrm{Nc}$ & $\begin{array}{c}0.067 * * * \\
(0.011)\end{array}$ & $\begin{array}{c}0.064 * * * \\
(0.009)\end{array}$ \\
\hline LNEMPHI & $\begin{array}{c}0.209 * * * \\
(0.006)\end{array}$ & $\begin{array}{c}-0.039 * * \\
(0.013)\end{array}$ & $\begin{array}{c}-0.032 * * \\
(0.012)\end{array}$ \\
\hline PATENT & $\mathrm{Nc}$ & $\begin{array}{c}-0.199 * * * \\
(0.030)\end{array}$ & $\begin{array}{c}-0.210^{* * *} \\
(0.029)\end{array}$ \\
\hline GP & $\begin{array}{c}0.159 * * * \\
(0.019)\end{array}$ & $\begin{array}{c}-0.269 * * * \\
(0.034)\end{array}$ & $\begin{array}{l}-0.254 * * * \\
(0.032)\end{array}$ \\
\hline ORGA & $\mathrm{Nc}$ & $\begin{array}{l}-0.016 \\
(0.036)\end{array}$ & $\begin{array}{c}0.002 \\
(0.033)\end{array}$ \\
\hline PUBLIC & $\mathrm{Nc}$ & $\begin{array}{c}0.128 * * * \\
(0.033)\end{array}$ & $\begin{array}{c}0.119 * * * \\
(0.032)\end{array}$ \\
\hline LNEXP & $\mathrm{Nc}$ & $\begin{array}{l}-0.004 * \\
(0.002)\end{array}$ & $\begin{array}{l}-0.003 \\
(0.002)\end{array}$ \\
\hline COOP & $\mathrm{Nc}$ & $\begin{array}{c}0.323 * * * \\
(0.033)\end{array}$ & $\begin{array}{c}0.336 * * * \\
(0.031)\end{array}$ \\
\hline TURNINC & $\begin{array}{c}0.117 * * * \\
(0.028)\end{array}$ & $\mathrm{Nc}$ & $\mathrm{Nc}$ \\
\hline TUNRDEC & $\begin{array}{l}-0.060 \\
(0.034)\end{array}$ & $\mathrm{Nc}$ & $\mathrm{Nc}$ \\
\hline LNWTURN & $\begin{array}{c}0.023 * * * \\
(0.004)\end{array}$ & $\mathrm{Nc}$ & $\mathrm{Nc}$ \\
\hline LNEXP*INTMAR & $\begin{array}{c}0.022 * * * \\
(0.001)\end{array}$ & $\mathrm{Nc}$ & $\mathrm{Nc}$ \\
\hline LNEXP*NATMAR & $\begin{array}{c}0.031 * * * \\
(0.002)\end{array}$ & $\mathrm{Nc}$ & $\mathrm{Nc}$ \\
\hline LNEXP*LOCMAR & $\begin{array}{c}0.017 * * * \\
(0.002)\end{array}$ & $\mathrm{Nc}$ & $\mathrm{Nc}$ \\
\hline EST & $\begin{array}{c}-0.378 * * * \\
(0.034)\end{array}$ & $\mathrm{Nc}$ & $\mathrm{Nc}$ \\
\hline Sectoral Dummies & No & Yes & Yes \\
\hline Country Dummies & Yes & Yes & Yes \\
\hline Lambda & $\mathrm{Nc}$ & $\mathrm{Nc}$ & $\begin{array}{c}0.001 \\
(0.019)\end{array}$ \\
\hline Percent concordant & 76.8 & 65.1 & 64.8 \\
\hline Likelihood & -22556.51 & -5734.57 & -6340.55 \\
\hline LR test $($ Beta $=0)$ & $8342.67 * * *$ & $614.80^{* * *}$ & $653.24 * * *$ \\
\hline LR test (dummies $=0)$ & $2104.58 * * *$ & $246.98 * * *$ & $257.7 * * *$ \\
\hline Observations & 46010 & 12530 & 12530 \\
\hline \multicolumn{4}{|c|}{$\begin{array}{l}\text { Note : LNRTOT: Total innovation expenditure of the firm, LNTURN : turnover of the firms, LNEMPHI: } \\
\text { higher education-skilled workforce, PATENT: takes the value } 1 \text { if the firm uses patent protection and } 0 \\
\text { otherwise, GP: dummy variable indicating whether the firm belongs to a group or not, ORGA: dummy variable } \\
\text { for organizational structure PUBLIC: public financial supports, LNEXP: exports as in CIS, COOP: firms } \\
\text { cooperate in innovation, LNWTURN: Firm turnover weighted by industry turnover, INTMAR: mainly } \\
\text { international market, NATMAR: mainly national market, LOCMAR: mainly local market, EST: dummy for } \\
\text { new established firm. } \\
\text { t-ratio are given in parenthesis level of significance: } * 10 \%, * * 5 \%, * * * 1 \% \\
\text { (Columns viii and ix: without correction of selection bias. Column x: with correction of selection bias) }\end{array}$} \\
\hline
\end{tabular}




\begin{tabular}{|c|c|c|}
\hline Variables & $\begin{array}{c}\text { Total Adoption made in isolation } \\
\text { without correction }(x i)\end{array}$ & $\begin{array}{c}\text { Total Adoption made in isolation } \\
\text { with correction }(x i i)\end{array}$ \\
\hline Intercept & $\begin{array}{l}0.266 * * * \\
(0.070)\end{array}$ & $\begin{array}{l}-0.600 \\
(0.412)\end{array}$ \\
\hline LNRTOT & $\begin{array}{l}-0.007 \\
(0.005)\end{array}$ & $\begin{array}{l}-0.005 \\
(0.005)\end{array}$ \\
\hline LNEMPHI & $\begin{array}{c}-0.058 * * * \\
(0.015)\end{array}$ & $\begin{array}{c}-0.066^{* * *} \\
(0.015)\end{array}$ \\
\hline PATENT & $\begin{array}{c}-0.278 * * * \\
(0.040)\end{array}$ & $\begin{array}{c}-0.370 * * * \\
(0.063)\end{array}$ \\
\hline GP & $\begin{array}{l}-0.094 * \\
(0.044)\end{array}$ & $\begin{array}{c}-0.201 * * \\
(0.069)\end{array}$ \\
\hline ORGA & $\begin{array}{c}-0.129 * * \\
(0.047)\end{array}$ & $\begin{array}{l}-0.091 \\
(0.049)\end{array}$ \\
\hline PUBLIC & $\begin{array}{l}-0.096^{*} \\
(0.045)\end{array}$ & $\begin{array}{l}-0.031 \\
(0.053)\end{array}$ \\
\hline LNEXP & $\begin{array}{l}-0.007^{*} \\
(0.003)\end{array}$ & $\begin{array}{c}-0.008 * * \\
(0.003)\end{array}$ \\
\hline COOP & $\begin{array}{l}-0.352 * * * \\
(0.044)\end{array}$ & $\begin{array}{l}-0.086 \\
(0.133)\end{array}$ \\
\hline Sectoral Dummies & Yes & Yes \\
\hline Country Dummies & Yes & Yes \\
\hline Lambda & $\mathrm{Nc}$ & $\begin{array}{l}0.817 * \\
(0.384)\end{array}$ \\
\hline Percent concordant & 67.8 & 67.9 \\
\hline Likelihood & -3275.12 & -3273.40 \\
\hline LR test $($ Beta $=0)$ & $7062.26 * * *$ & $513.47 * * *$ \\
\hline LR test (dummies $=0)$ & $182.56 * * *$ & $187 * * *$ \\
\hline Observations & 5599 & 5599 \\
\hline \multicolumn{3}{|c|}{$\begin{array}{l}\text { Note: LNRTOT: Total innovation expenditure of the firm, LNTURN : turnover of the firms, LNEMPHI } \\
\text { higher education-skilled workforce, PATENT: takes the value } 1 \text { if the firm uses patent protection and } 0 \\
\text { otherwise, GP: dummy variable indicating whether the firm belongs to a group or not, ORGA: dummy variable } \\
\text { for organizational structure PUBLIC: public financial supports, LNEXP: exports as in CIS, COOP: firms } \\
\text { cooperate in innovation } \\
\text { t-ratio are given in parenthesis level of significance: } * 10 \%, * * 5 \%, * * * 1 \%\end{array}$} \\
\hline
\end{tabular}

\footnotetext{
${ }^{16}$ The selection equation is not reported here because it is the same equation as the equation $(i)$ reported in Table 1. Moreover, results for total adoption made in cooperation are not reported since they are exactly opposite to the one obtained for total adoption made in isolation (the dependent variable being dichotomous).
} 
Appendix:

\begin{tabular}{|c|c|c|c|c|c|}
\hline & Mean & Std. Dev. & Min & Max & Num. Obs. \\
\hline LNRTOT & 4.970 & 5.93 & 0 & 22.179 & 29010 \\
\hline LNTURN & 14.275 & 2.213 & 0 & 24.532 & 47759 \\
\hline LNEMPHI & 1.747 & 1.473 & 0 & 10.073 & 47045 \\
\hline PATENT & 0.213 & 0.409 & 0 & 1 & 47759 \\
\hline GP & 0.215 & 0.411 & 0 & 1 & 48790 \\
\hline ORGA & 0.509 & 0.500 & 0 & 1 & 47759 \\
\hline PUBLIC & 0.070 & 0.255 & 0 & 1 & 47759 \\
\hline LNEXP & 6.500 & 6.723 & 0 & 23.981 & 45324 \\
\hline COOP & 0.293 & 0.455 & 0 & 1 & 14217 \\
\hline TURNINC & 0.110 & 0.313 & 0 & 1 & 49064 \\
\hline TUNRDEC & 0.067 & 0.251 & 0 & 1 & 49061 \\
\hline LNWTURN & 12.805 & 2.463 & 0 & 23.869 & 47712 \\
\hline LNEXP*INTMAR & 3.206 & 6.005 & 0 & 23.981 & 45324 \\
\hline LNEXP*NATMAR & 2.239 & 4.855 & 0 & 21.184 & 45324 \\
\hline LNEXP*LOCMAR & 1.036 & 3.348 & 0 & 20.978 & 45324 \\
\hline EST & 0.048 & 0.215 & 0 & 1 & 49139 \\
\hline Adoption & 0.125 & 0.331 & 0 & 1 & 49139 \\
\hline Product adoption & 0.041 & 0.199 & 0 & 1 & 47759 \\
\hline Process adoption & 0.059 & 0.235 & 0 & 1 & 47759 \\
\hline $\begin{array}{l}\text { Cooperation-based } \\
\text { adoption }\end{array}$ & 0.277 & 0.447 & 0 & 1 & 14145 \\
\hline $\begin{array}{l}\text { Other } \\
\text { organisations- } \\
\text { based adoption }\end{array}$ & 0.126 & 0.332 & 0 & 1 & 14145 \\
\hline
\end{tabular}

